\title{
Determination of Rank, Rankl and Opg Gene Polymorphisms in Triple-Negative Breast Cancer Patients and Investigation of its Effect on Bone Metastasis
}

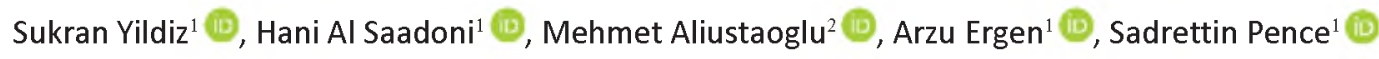 \\ ${ }^{1}$ Istanbul University, Aziz Sancar Institute of Experimental Medicine, Department of Molecular Medicine \\ ${ }^{2}$ Kartal Dr. Lutfi Kirdar Training and Research Hospital, Department of Internal Medicine and Oncology \\ Correspondence Author: Arzu Ergen \\ E-mail: aergen@istanbul.edu.tr \\ Received: 28.02.2019 Accepted: 27.09.2019
}

\begin{abstract}
Objective: Triple negative breast cancer (TNBC) is a sub-type of breast cancer with the worst prognosis and highest risk of mortality. Bone metastasis is the most common metastasis type among women with breast cancer. RANK and OPG, are the members of the family of tumor necrosis factor (TNF), which is effective on osteoblastic and osteoclastic mechanisms. RANKL, interacts with RANK and leads to bone resorption, whereas it inhibits bone destruction when it interacts with OPG.

Methods: In this study, we investigated the polymorphisms of RANK, RANKL and OPG genes and their effects on bone metastasis in 45 patients with triple negative breast cancer and 30 healthy controls, using PCR, RFLP and agarose gel electrophoresis techniques.

Results: The RANKL genotype and allele distribution analysis revealed a significantly increased CC genotype incidence in patients with TNBC and bone metastasis $(p=0.011$ ) and in those without bone metastasis $(p=0.004)$ compared to the control group. The OPG genotype and allele distribution analysis revealed significantly increased $C$ allele incidence in patients with TNBC and bone metastasis $(p=0.004)$ compared to the control group. Likewise, the $C C$ genotype $(p=0.001)$ and $C$ allele incidences $(p=0.001)$ were observed to be significantly increased in patients with TNBC compared to healthy controls.

Conclusion: This study is one of the first studies investigating all three RANK/RANKL/OPG gene polymorphisms and the relationship between breast cancer and bone metastasis in our country. We believe that our study will shed light onto further studies to be conducted on triple negative breast cancer and bone metastasis.
\end{abstract}

Keywords: Breast, metastasis, triple negative

\section{INTRODUCTION}

Breast cancer is the most common cancer type among women. According to the 2013 statistics of Türkiye, breast cancer was observed to be the most common type of cancer among women with a rate of $24.6 \%$, whereas this rate was observed to be $24.9 \%$ in the 2014 statistics (1). Breast cancer may develop as a result of various risk factors such as gender, age, family history, age of menarche and menapause, age of first pregnancy, radiation, obesity, smoking and alcohol use $(2,3)$.

According to the molecular classification system, breast cancer has been grouped as Luminal A, Luminal B, HER2positive, Triple negative and Null type. The worst prognosis among all belongs to the triple negative sub-type, which has the highest risk of mortality $(4,5)$.

Triple negative breast cancer (TNBC) constitutes $10-20 \%$ of all breast cancers. According to a study, more than 170.000 cases among one million cancer cases worldwide had the triple negative phenotype (6-8). Expression of none of the estrogen (ER), progesterone (PR) and HER2 (human epidermal growth factor 2) receptors was observed in cases with TNBC. Since hormone receptors are negative, there is no effective treatment strategy except chemotherapy. The current treatment methods target ER, PR and HER2, and therefore, new treatment strategies are needed for patients with $\operatorname{TNBC}(6,9,10)$.

Breast cancer may lead to pulmonary, hepatic and bone metastases, the latter of which is the most common type. Metabolism of bone tissue is regulated by osteoblasts, which are bone constructive, and osteoclasts, which are bone destructive (11-13). RANK, RANKL and OPG are members of the tumor necrosing factor (TNF) family, which are effective on both osteoblasts and osteoclasts. The RANK-RANKL-OPG signaling pathway was first described in the 1990s, and was observed to have roles in physiological functions beyond bone biology, such as deleopment of lymph nodes, hormone control in breast cancer and bone metastasis. RANKL and OPG are secreted from osteoblasts. RANKL interacts with its receptor, RANK, which is on the surface of osteoclasts, and leads to bone resoprtion, When it interacts with OPG, it inhibits bone catabolism. OPG in turn binds to RANKL and inhibits its interaction with RANK, providing maintenance of the skeletal integrity (14-17).

The aim of this study was to define the polymorphisms of RANK, RANKL and OPG genes and to investigate the 
relationship between these genes and bone metastasis in patients with triple negative breast cancer.

\section{METHODS}

\subsection{Patient Selection}

The study included a total of 45 patients with triple negative breast cancer diagnosed in the Medical Oncology Clinics; among these, 30 had no metastasis and 15 had bone metastases, and 30 healthy individuals without the risk of cancer, after having obtained their written informed consents. Ethics committee approval was received for this study from the medical ethics committee of Istanbul Medical Faculty (No:681/2016). Blood samples were collected subsequent to ethical committee approval and all patients had not recieved any chemo - or radiotherapy protocol.

\subsection{Genomic DNA Isolation}

The DNA isolation of the peripheral blood samples collected from the patients and healthy individuals was performed using the Invitrogen DNA isolation kit (Invitrogen, K182001).

\subsection{Primer Design for Detemination of Polymorphisms}

In this study, rs35211496 C/T polymorphism was selected for the RANK gene, rs9533156 T/C polymorphism was seleceted for te RANKL gene, and rs $2073618 \mathrm{G} / \mathrm{C}$ polymorphism was selected for the OPG gene. The following primers were designed using the virtual PCR (Primer 3 Input version 4.0.0) method.

For the RANK gene; Forward primer: 5' - CGCCGCAACACCGAGT - 3'

Reverse primer: 5' - ATGGCTCAGCAAGAGCCGAC-3'

For the RANKL gene; Forward Primer: $5^{\prime}$ - CCTGACTGTTGGGTGAGCC $-3^{\prime}$

Reverse Primer: 5' - CAACCTCTCCCCCCAAA - 3' For OPG gene;

Forward Primer: $5^{\prime}$ - TGATCAAAGGCAGGCGATACT - 3'

Reverse Primer: 5' - TGGCCCAGGGACTTACCA - 3'

\subsection{Determination of Polymorphisms}

Proper polymerization of RANK, RANKL and OPG gene regions with their virtually designed primers in genomic DNA samples previously isolated from blood was performed according to the following procedure:

For each DNA sample, a total of $25 \mu \mathrm{l}$ PCR mix was prepared.

The PCR Master mix included: for each reaction of $25 \mu \mathrm{l}$, $0.75 \mathrm{U}$ Taq DNA Polymerase, Buffer, $2 \mathrm{mM} \mathrm{MgCl}, 250 \mu \mathrm{M}$ dNTPs and enzyme stabilizer. The samples were placed into the PCR device (Bio-Rad T100 Thermal Cycler), which was run according to the procedure of each different gene. PCR conditions for RANK; $95 \circ \mathrm{C} 5 \mathrm{~m}$; $94{ }^{\circ} \mathrm{C} 45 \mathrm{sec}, 65{ }^{\circ} \mathrm{C} 45 \mathrm{sec}, 72^{\circ} \mathrm{C}$ $45 \mathrm{sec}, 35$ cycle; $72 \circ \mathrm{O} 5 \mathrm{~m}$, for RANKL; $95 \circ \mathrm{C} 5 \mathrm{~m}$; 94 으 $45 \mathrm{sec}$, $59^{\circ} \mathrm{C} 45 \mathrm{sec}, 72^{\circ} \mathrm{C} 45 \mathrm{sec}, 30 \mathrm{cycle}$; $72^{\circ} \mathrm{C} 5 \mathrm{~m}$, for OPG; $95^{\circ} \mathrm{C}$

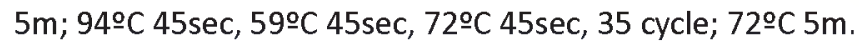

For the amplified gene regions obtained from RANK, RANKL and OPG genes, enzymes and restriction sites were determined using the NEB cutter V2.0 tool. The BseYI enzyme was used for RANK rs35211496 C/T polymorphism, The HpyCH4III enzyme was used for the RANKL rs9533156 $\mathrm{T} / \mathrm{C}$ polymorphism, and the Bbvl enzyme was used for the OPG rs2073618 G/C poymorphism. Post-restriction products were loaded on $3 \%$ agarose gel.

\subsection{Statistical Analysis}

Categorical variables such as genotypes and alleles were compared using the Chi-square $\left(\chi^{2}\right)$ test. Allele and genotype frequencies were determined through direct counting. Whenever an expected cell value of less than 5 was obtained, Fisher's exact test was used. Differences in continuous variables between carriers and the control subjects were tested using Student's t test. Statistical analyses were performed using the SPSS 21.0 software (SPSS Inc., Chicago, USA).

\section{RESULTS}

The mean age among 30 patients with TNBC and without metastasis was $51.33 \pm 9.96$, and the mean age among 15 patients with metastasis was $53.71 \pm 9.47$. The mean age among healthy individuals was $50.58 \pm 8.87$. No difference was observed between the groups ( $p>0.05)$. All demographical parameters are shown in Table 1.

Table 1. Demographical parameters of study groups

\begin{tabular}{|c|c|c|c|}
\hline Demographical Parameters & $\begin{array}{l}\text { TNBC without } \\
\text { metastasis } \\
(n=30)\end{array}$ & $\begin{array}{c}\text { TNBC } \\
\text { with bone } \\
\text { metastasis } \\
(n=15) \\
\end{array}$ & $\begin{array}{l}\text { Control } \\
(n=30)\end{array}$ \\
\hline \multicolumn{4}{|l|}{ T Stage (\%) } \\
\hline $\mathrm{T} 1$ & 13.8 & - & - \\
\hline $\mathrm{T} 2$ & 48.3 & - & - \\
\hline T3 & 34.5 & 60 & - \\
\hline $\mathrm{T} 4$ & 3.4 & 40 & - \\
\hline \multicolumn{4}{|l|}{ Lymph node metastasis (\%) } \\
\hline No & 58.6 & - & - \\
\hline N1 & 13.8 & 6.7 & - \\
\hline N2 & 13.8 & 20 & - \\
\hline N3 & 13.8 & 73.3 & - \\
\hline Lymphatic Invasion (\%) & 13.8 & 73.3 & - \\
\hline \multicolumn{4}{|l|}{ Differantitation (\%) } \\
\hline Moderate (G2) & 55.2 & 20 & \\
\hline Poor (G3) & 44.8 & 80 & - \\
\hline \multicolumn{4}{|l|}{ Histological Parameters (\%) } \\
\hline Lobullary & 24.1 & 6.7 & - \\
\hline Ductal & 62.1 & 73.3 & - \\
\hline Mix & 13.8 & 20 & - \\
\hline \multicolumn{4}{|l|}{ Tumor Localization (\%) } \\
\hline Right & 27.6 & 26.7 & \\
\hline Left & 72.4 & 60 & \\
\hline Bilateral & - & 13.3 & \\
\hline \multicolumn{4}{|l|}{ Menopause (\%) } \\
\hline Premenopause & 46.7 & 6.7 & 57.1 \\
\hline Postmenopause & 53.3 & 93.3 & 42.9 \\
\hline Smoking (\%) & 36.7 & 53.3 & 19 \\
\hline
\end{tabular}


The genotype and allele distribution of the RANKL, RANK and OPG gene variants of the study groups have been presented in the Table 2. No difference was determined between the study groups with regard to the RANK genotype and allele distribution ( $p>0.05$ ). When the RANKL genotype and allele distribution were analyzed, the $C C$ genotype was observed to be significantly increased in patients with TNBC and bone metastasis ( $p=0.011,95 \% \mathrm{Cl}=1.59-29.95)$, and in patients with TNBC and no bone metastasis ve $\left(p=0.004, \chi^{2}=8.14\right.$, OR: $4.75,95 \% \mathrm{Cl}=1.58-14.24)$, compared to the control group. The T allele incidence was observed to be statistically increased in the control group in patients with TNBC and bone metastasis $(\mathrm{p}=0.011,95 \% \mathrm{Cl}=1.11-9.03)$ and in patients with TNBC and no bone metastasis $\left(p=0.004, \chi^{2}=8.14\right.$, OR: 2.37 , $95 \% \mathrm{Cl}=1.23-4.56)$.

Table 2. Distribution of RANKL, RANK and OPG gene variants in study groups

\begin{tabular}{|c|c|c|c|}
\hline RANKL & $\begin{array}{c}\text { TNBC without } \\
\text { metastasis } \\
(n=30)\end{array}$ & $\begin{array}{c}\text { TNBC with bone } \\
\text { metastasis } \\
(n=15)\end{array}$ & $\begin{array}{l}\text { Control } \\
\{n=30\rangle\end{array}$ \\
\hline CC (n/\%) & $22 / 73.3^{* *}$ & $12 / 80^{*}$ & $11 / 36.7$ \\
\hline$\pi(n / \%)$ & $1 / 3.3$ & & $6 / 20$ \\
\hline $\mathrm{TC}(\mathrm{n} / \%)$ & $7 / 23.3$ & $3 / 20$ & $13 / 43.3$ \\
\hline$C(n / \%)$ & $51 / 85$ & $25 / 89.3$ & $35 / 58.3$ \\
\hline$T(n / \%)$ & $9 / 15$ & $3 / 10.7$ & $25 / 41.7^{* * * *}$ \\
\hline RANK & $\begin{array}{l}\text { TNBC without } \\
\text { metastasis } \\
(n=30)\end{array}$ & $\begin{array}{c}\text { TNBC with bone } \\
\text { metastasis } \\
(n=15)\end{array}$ & $\begin{array}{l}\text { Control } \\
(n=30)\end{array}$ \\
\hline $\mathrm{CC}(\mathrm{n} / \%)$ & $11 / 36.7$ & $2 / 13.3$ & $9 / 30$ \\
\hline$\pi(n / \%)$ & $11 / 36.7$ & $10 / 66.7$ & $11 / 36.7$ \\
\hline $\mathrm{CT}(\mathrm{n} / \%)$ & $8 / 26.7$ & $3 / 20$ & $10 / 33.3$ \\
\hline$C(n / \%)$ & $30 / 50$ & $7 / 23.3$ & $28 / 46.6$ \\
\hline$T(n / \%)$ & $30 / 50$ & $23 / 76.7$ & $32 / 53.4$ \\
\hline OPG & $\begin{array}{l}\text { TNBC without } \\
\text { metastasis } \\
(n=30)\end{array}$ & $\begin{array}{c}\text { TNBC with bone } \\
\text { metastasis } \\
(n=15)\end{array}$ & $\begin{array}{l}\text { Control } \\
(n=30)\end{array}$ \\
\hline$G G(n / \%)$ & $4 / 13.3$ & $2 / 13.3$ & $18 / 60^{* * *}$ \\
\hline $\mathrm{CC}(\mathrm{n} / \%)$ & $22 / 73.3^{* *}$ & $11 / 73.3^{*}$ & $3 / 10$ \\
\hline $\mathrm{GC}(\mathrm{n} / \%)$ & $4 / 13.3$ & $2 / 13.3$ & $9 / 30$ \\
\hline$G(n / \%)$ & $12 / 20$ & $6 / 20$ & $45 / 75^{* * *}$ \\
\hline$C(n / \%)$ & $48 / 80 * *$ & $24 / 80^{*}$ & $15 / 25$ \\
\hline
\end{tabular}

$n=$ Number of subjects, * TNBC with bone metastasis vs control, ** TNBC without metastasis, vs control, ${ }^{* * *}$ control vS TNBC with and without metastasis

The OPG genotype and allele distribution analysis revealed that the $C$ allele incidence among patients with bone metastasis was significantly increased compared to that of the control group $(p=0.004,95 \% \mathrm{Cl}=0.28-0.74)$. The incidence of OPG GG genotype, on the other hand, was observed to be increased in the control group ( $p=0.004,95 \%$ $\mathrm{Cl}=1.19-16.89)$. Likewise, both the $\mathrm{CC}$ genotype $(\mathrm{p}=0.001$, $95 \% \mathrm{Cl}=0.04-0.40)$ and the $\mathrm{C}$ allele $(\mathrm{p}=0.001,95 \% \mathrm{Cl}=2.70$ 35.11 ) incidences were observed to be significantly increased in patients with TNBC compared to the control group. The GG genotype in the control group $(p=0.001,95 \% \mathrm{Cl}=1.72-11.72)$ and the G allele $(\mathrm{p}=0.001,95 \% \mathrm{Cl}=0.10-1.71)$ were observed to be significantly increased compared to the patient group with TNBC.

No significant difference was determined in the RANKL, RANK and OPG genotype and allele distribution, and the demographic parameters between the patient groups ( $p>0.05)$.

\section{DISCUSSION}

Breast cancer has been diagnosed in one million women worldwide every year. Among these, more than 170.000 are the triple negative sub-type (18). It was reported in the study of Aksoy et al. (2007) on 928 patients with breast cancer that $11.7 \%$ of the patients with breast cancer belonged to the triple negative sub-type in Turkey $(19,20)$. Triple negatif breast cancer is the sub-type with aggressive tumor characteristics of breast cancer and a different etiology copared to the other types. Since it does not have ER, PR and HER2 protein receptors, treatment options such as monoclonal antibodies or hormones are useless. Therefore, the mortality rate in TNBC is highest among all the other types (5). It has been reported that $75 \%$ of distant organ metastases are bone metastases in patients with TNBC (4).

The RANK/RANKL pathway is one of the target pathways of the treatment due to its efficacy on cell differentiation and anti-apoptotic pathway in triple negative breast cancer and bone metastasis $(21,22)$.

This study attempted to examine potential association between RANK/RANKL/OPG polymorphisms and breast cancer. This is the first study focused on the potential contribution of RANK/RANKL/OPG polymorphisms to breast cancer pathogenesis and bone metastasis in Turkey.

In our study, no significant correlation was determined between all three groups with regard to RANK genotype and allele distributions $(p>0.05)$. Hein et al. reported no correlation between the prognosis of bone metastasis and RANK rs35211496 C/T polymorphism in breast cancer (23). It was concluded in the study of Santini et al. on patients with breast cancer that RANK led to the development of bone metastasis in breast cancer (24). Yin et al. reported a correlation between RANK rs $1805034 \mathrm{~T} / \mathrm{C}$ polymorphism and esophageal squamous cell carcinoma (25).

It was observed in our study that RANKL rs9533156 CC genotype incidence was significantly increased in patients with TNBC and bone metastasis $(p=0.011)$ and those with no bone metastasis $(p=0.004)$, compared to the control group. In the control group, the incidence of the mutant type $T$ 
allele was observed to be significantly increased compared to patients with TNBC and bone metastasis $(p=0.011)$ and those with no bone metastasis $(p=0.004)$. Our results showed that RANKL rs9533156 T allele might play a protective role against to TNBC without bone metastasis. In another study, the RANKL rs9533156 polymorphism was found to be significantly different between patients and healthy individuals and $T$ allele was observed to be more common among patients with breast cancer (26). Reyes et al. demonstrated that RANK/ RANKL co-expression was related to survival in triple negative breast cancer (27). Our findings show that $t$ allele may play a protective role in contrast to other studies. Turkey's genetic diversity can cause us to achieve these results.

The OPG rs2073618 polymorphism analysis of our study revealed that the mutant type $C$ allele and $C C$ genotype might be a risk factor for breast cancer with and without metastasis. In a study conducted on patients with breast cancer and OPG rs2073618 G/C polymorphism, the $C$ allele incidence was observed to be higher compared to controls (28). In another study, C allele was determined to be very high among the patients (29). Shaker et al suggested that SNPs in RANKL, OPG, CHI3L1, and VDR genes via genegene interaction may help predict Breast cancer risk and prognosis (30). Osteoclast activation is induced by RANK/ RANKL and suppressed by OPG. Wang et al suggested that OPG rs2073618 CC genotype is associated with lower serum OPG levels and a higher RANKL/OPG ratio. Hence, a higher RANKL/OPG ratio might increase bone resorption (28). Our finding confirms other studies on literature because we found $\mathrm{CC}$ genotype and $\mathrm{C}$ allele were significantly increased in both patients groups. Conversely, in another study, they found no correlation between OPG rs2073618 polymorphism and breast cancer (31).

Among the study groups, no significant difference was observed between the patient groups with regard to RANKL, RANK and OPG genotype and allele distribution, and the demographic parameters $(p>0,05)$.

There are some limitations in this study. First, number of patients are needed to much larger and secondly to determine of serum OPG, RANK and RANKL levels in study groups using ELISA technique, as a supporter of our SNP results.

\section{CONCLUSION}

Different from the studies in the literature, our study is one of the first studies investigating all three RANK/RANKL/OPG gene polymorphisms and the relationship between breast cancer and bone metastasis in our country. We believe that our study will shed light onto further studies to be conducted on triple negative breast cancer and bone metastasis.

Acknowledgements: This study was funded by Scientific Research Projects Coordination Unit of Istanbul University. Project number: 22251

\section{REFERENCES}

[1] T.C. Sağlık Bakanlığı 2013, 2014 Türkiye Kanser İstatistikleri. Ankara: Halk Sağlığı Genel Müdürlüğü, 2014, Erişim 17.11.2017, http://kanser.gov.tr/daire-faaliyetleri/kanseristatistikleri/2106-2013-yıl -türkiye-kanser-istatistikleri. html (Turkish)

[2] Mavaddat N, Antoniou AC, Easton DF, Garcia-Closas M. Genetic susceptibility to breast cancer. Mol Oncol 2010; 4(3):174-191.

[3] Nurten R, Buyukbabani N, Bermek E, Ilhan R, Iplikci A. Hormon reseptörlerinin meme karsinomlarının histopatolojik tiplerine göre değerlendirilmesi. Türk Patoloji Dergisi 1998; 4-1;46-51 (Turkish)

[4] Tekin V, Yıldırım M, Erkan N, Postacı H, Çetin DA, Selek E, Genç L. Meme kanserli subgruplarının sıklığı ve sağkalım üzerine etkileri. İzmir Eğitim ve Araştırma Hastanesi Tıp Dergisi 2013;17:88-97 (Turkish).

[5] Kuo WH, Chang YY, Lai LC, Tsai MH, Hsiao CK, Chang KJ, Chuang EY. Molecular characteristics and metastasis predictor genes of triple-negative breast cancer: a clinical study of triplenegative breast carcinomas. PloS one 2012; 7(9):e45831.

[6] Hudis CA, Gianni L. Triple-negative breast cancer: an unmet medical need. The Oncologist 2011;16(1):1-11

[7] Lehmann BD, Bauer JA, Chen X, Sanders ME, Chakravarthy AB, Shyr $Y$, Pietenpol JA. Identification of human triple-negative breast cancer subtypes and preclinical models for selection of targeted therapies. J Clin Invest 2011;121(7):2750-2767.

[8] Swain S. Triple-negative breast cancer: Metastatic risk and role of platinum agents. Presented at the Annual Meeting of the American Society for Clinical Oncology; Clinical Science Symposium; Chicago; 2008

[9] Pala EE, Bayol Ü, Cumurcu S, Keskin E. Triple-Negatif/Bazal Benzeri Meme Kanserinin İmmünohistokimyasal Özellikleri. Türk Patoloji Derg 2012; 28: 238-244 (Turkish).

[10] Wahba HA, El-Hadaad HA. Current approaches in treatment of triple-negative breast cancer. Cancer Biol Med 2015; 12(2):106.

[11] Muss HB. Breast cancer and differential diagnosis of benign nodules, in Cecil Textbook of Medicine, JCB L Goldman, Editor. W.B. Saunders: Philadelphia. 2000. p.1373-1380

[12] Lorenzo JA, Canalis E, Raisz LG. Metabolic bone dissease. Williams Textbook Of Endocrinology, 11th Edn. Kronenberg HM, Melmed S, Polonsky KS, Larsen PR, editors. Saunders Elsevier: Philadelphia. 2007. p.1296-1310.

[13] Ando K, Mori K, Rédini F, Heymann D. RANKL/RANK/OPG: key therapeutic target in bone oncology. Curr Drug Discov Technol 2008;5(3):263-268.

[14] Boyce BF, Xing L. Functions of RANKL/RANK/OPG in bone modeling and remodeling. Arch Biochem Biophys. 2008; 473(2):139-146.

[15] Emery JG, McDonnell P, Burke MB, Deen KC, Lyn S, Silverman C, Dul E, Appelbaum ER, Eichman C, DiPrinzio R, Dodds RA, James IE, Rosenberg M, Lee JC, Young PR.. Osteoprotegerin is a receptor for the cytotoxic ligand TRAIL. J Biol Chem 1998; 273(23):14363-14367.

[16] American Society for Bone and Mineral Research President's Committee on Nomenclature. Proposed standard nomenclature for new tumor necrosis factor family members involved in the regulation of bone resorption. The American Society for Bone and Mineral Research President's Committee on Nomenclature. J Bone Miner Res 2000;15(12):2293-2296. 
[17] Suvannasankha A, Chirgwin JM. Role of bone-anabolic agents in the treatment of breast cancer bone metastases. Breast Cancer Research 2014; 16(6): 484.

[18] Mansour EG, Rravdin PM, Dressler L. Prognostic factors in early breast cancer. Cancer 1994;74:381-400.

[19] Aksoy S, Dizdar O, Harputluoglu H, Altundag K. Demographic, clinical, and pathological characteristics of Turkish triplenegative breast cancer patients: single center experience. Ann Oncol 2007; 18(11): 1904-1906.

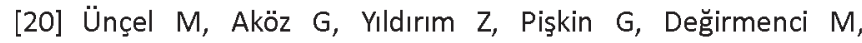
Solakoğlu Kahraman D, Ayaz D, Akbulut G, Diniz G. Meme kanserinin klinikopatolojik özelliklerinin moleküler alt tipe göre değerlendirilmesi. Tepecik Eğit ve Araşt Hast Dergisi 2015;25(3):151-156

[21] Li R, Zhang K, Penedo TL, Kragel CP, Grizzle WE, Hameed O, Siegal GP, Wei S. The RANK Pathway in Advanced Breast Cancer: Does Src Play a Role? Appl Immunohistochem Mol Morphol 2016;24(1):42-50.

[22] Weichhaus M, Segaran P, Renaud A, Geerts D, Connelly L. Osteoprotegerin expression in triple-negative breast cancer cells promotes metastasis. Cancer Med 2014;3(5):1112-25.

[23] Hein A, Bayer CM, Schrauder MG, Häberle L, Heusinger $K$, Strick R, Ruebner M, Lux MP, Renner SP, Schulz-Wendtland $R$, Ekici $A B$, Hartmann $A$, Beckmann MW, Fasching PA. Polymorphisms in the RANK/RANKL genes and their effect on bone specific prognosis in breast cancer patients. Biomed Res Int. 2014;2014:842452.

[24] Santini D, Schiavon G, Vincenzi B, Gaeta L, Pantano F, Russo A, Ortega C, Porta C, Galluzzo S, Armento G, La Verde N, Caroti C, Treilleux I, Ruggiero A, Perrone G, Addeo R, Clezardin P, Muda $A O$, Tonini G. Receptor activator of NF-kB (RANK) expression in primary tumors associates with bone metastasis occurrence in breast cancer patients. PLoS One 2011;6(4):e19234.
[25] Yin J, Wang L, Tang W, Wang X, Lv L, Shao A Shi Y, Ding G, Chen $S$, Gu H RANK rs1805034 T>C polymorphism is associated with susceptibility of Esophageal Cancer in a Chinese Population. PLoS One 2014;9(7):e101705.

[26] Thomson CA, McCullough ML, Wertheim BC, Chlebowski RT, Martinez ME, Stefanick ML, Rohan TE, Manson JE, Tindle HA, Ockene J, Vitolins MZ, Wactawski-Wende J, Sarto GE, Lane DS, Neuhouser ML. Nutrition and Physical Activity Cancer Prevention Guidelines, Cancer Risk, and Mortality in the Women's Health Initiative. Cancer Prev Res 2014;7(1): 42-53

[27] Reyes ME, Fujii T, Branstetter D, Krishnamurthy S, Masuda $H$, Wang X, Reuben JM, Woodward WA, Edwards BJ, Hortobagyi GN, Tripathy D, Dougall WC, Eckhardt BL, Ueno NT. Poor prognosis of patients with triple-negative breast cancer can be stratified by RANK and RANKL dual expression. Breast Cancer Res Treat 2017;164(1):57-67.

[28] Wang J, Lu K, Song Y, Zhao S, Ma W, Xuan Q, Tang D, Zhao H, Liu L, Zhang Q. RANKL and OPG polymorphisms are associated with aromatase inhibitor-related musculoskeletal adverse events in Chinese Han Breast Cancer Patients. PLoS One 2015;10 (7):e0133964

[29] Omar HS, Shaker OG, Nassar YH, Marzouk SA, El Marzouky MS. The association between RANKL and osteoprotegerin gene polymorphisms with breast cancer. Mol Cell Biochem 2015; 403(1-2):219-229.

[30] Shaker OG, Senousy MA. Association of SNP-SNP Interactions Between RANKL, OPG, CHI3L1, and VDR Genes With Breast Cancer Risk in Egyptian Women. Clin Breast Cancer. 2019;19(1):e220-e238.

[31] Ney JT, Juhasz-Boess I, Gruenhage F, Graeber S, Bohle RM, Pfreundschuh M, Solomayer EF, Assmann G. Genetic polymorphism of the OPG gene associated with breast cancer. BMC Cancer 2013;13(1): 40 . 